\title{
Pemanfaatan Jerami Padi Sebagai Bioplastik Dengan Menggunakan Metode Perlakuan Pelarut Organik
}

\section{Adhi Setiawan*, Febby Dwi Melanny Anggraini, Tarikh Azis Ramadani, Luqman Cahyono, Mochammad Choirul Rizal}

\author{
Program Studi Teknik Pengolahan Limbah, Jurusan Teknik Permesinan Kapal, \\ Politeknik Perkapalan Negeri Surabaya \\ Jl. Teknik Kimia Kampus ITS Sukolilo Surabaya, Indonesia \\ Email: adhistw23@gmail.com
}

\begin{abstract}
Abstrak
Jerami padi memilki kandungan selulosa yang dapat dimanfaatkan sebagai bahan baku pembuatan bioplastik. Penelitian ini bertujuan untuk mensintesis bioplastik dari bahan baku jerami padi menggunakan perlakuan pelarut organik serta menganalisis pengaruh rasio massa pati dengan selulosa karakteristik produk bioplastik. Proses delignifikasi jerami menggunakan larutan etanol $5 \%$ dan $35 \%$ pada suhu $80^{\circ} \mathrm{C}$ selama dua jam. Bioplastik dibuat dengan rasio massa pati dengan selulosa sebesar $1: 0,5 ; 1: 1$; dan 1:1,5. Karakterisasi menggunakan metode SEM, XRD, TG-DTA, uji tarik, uji transmisi uap, serta uji degradasi. Hasil penelitian menunjukkan bahwa proses delignifikasi menggunakan etanol menyebabkan peningkatan kadar selulosa serta kristalinitas jerami. Morfologi bioplastik menunjukkan permukaan yang tidak rata serta terdapat bagian matriks yang terpisah dengan fiber. Hasil TG-DTA menunjukkan pengurangan massa bioplastik sebesar $81,01 \%$ pada suhu $550^{\circ} \mathrm{C}$. Hasil kuat tarik terbaik pada bioplastik yang dibuat dengan rasio massa pati dengan selulosa 1:0,5 pada konsentrasi delignifikasi etanol 35\%. Nilai kuat tarik yang diperoleh sebesar 8,773 Mpa. Pengujian degradasi bioplastik dilakukan selama 10 hari diperoleh nilai \% degradasi terbesar bioplastik adalah sebesar $99,9 \%$.
\end{abstract}

Kata kunci : Bioplastik, Jerami, Perlakuan Pelarut Organic, Selulosa

\section{Abstract \\ Utilization of Rice Straw as Bioplastic Using Organic Solvent Treatment Method}

Rice straw contains cellulose which can be used as raw material for making bioplastics. This study aims to synthesize bioplastics from rice straw using organic solvent treatment and analyze the effect of the mass ratio of starch to cellulose on the characteristics of bioplastic products. The straw delignification process used $5 \%$ and $35 \%$ ethanol solution at $80^{\circ} \mathrm{C}$ for two hours. Bioplastics are made with a mass ratio of starch to cellulose of 1:0.5; 1:1; and 1:1.5. Characterization using SEM, XRD, TG-DTA methods, tensile test, vapour transmission test, and degradation test. The results showed that the delignification process using ethanol caused an increase in cellulose content and straw crystallinity. The morphology of the bioplastic shows an uneven surface and there are parts of the matrix that are separated from the fiber. The results of TG-DTA showed a reduction the mass of bioplastic by $81.01 \%$ at a temperature of $550^{\circ} \mathrm{C}$. The best tensile strength results in bioplastics made with a mass ratio of starch to cellulose 1:0.5 at a delignification concentration of 35\% ethanol. The tensile strength value obtained was 8,773 Mpa. The bioplastic degradation test was carried out for 10 days and the largest percentage of bioplastic degradation was $99.9 \%$.

Keywords : Bioplastic, Rice Straw, Organic Solvent Treatment, Cellulose 


\section{PENDAHULUAN}

Plastik merupakan salah satu material yang sering digunakan oleh manusia karena serba guna dan praktis. Produksi plastik telah meningkat secara signifikan selama tujuh puluh tahun terakhir dan diperkirakan telah mencapai lebih dari 365 juta ton pada Tahun 2016. Plastik dibuat dengan menggunakan bahan utama yang tak terbarukan dan sulit terurai (Thompson et al., 2009). Polimer dari plastik pada umumnya mengandung bahan aditif seperti stabilizer, pigmen, dan komponen lain yang bersifat racun seperti halnya antioksidan, flame retardant, dan blowing agent (Hahladakis et al., 2018). Jumlah produksi sampah plastik yang yang sangat besar merupakan salah satu ancaman terhadap masalah lingkungan serta kesehatan manusia. Bahkan, plastik merupakan komponen utama dalam sampah perkotaan yang sulit terdegradasi sehingga dapat bertahan selama puluhan tahun. Sifat tersebut menyebabkan sampah plastik perlu pengelolaan yang memadai (Bayer et al., 2014). Pengembangan material baru yang inovatif dan ramah lingkungan sangat diperlukan untuk mengurangi dampak negatif akibat penggunaan plastik. Bioplastik merupakan generasi plastik baru sebagai alternatif pengganti plastik konvensional di masa mendatang sehingga dapat mengurangi timbulan sampah plastik.

Bioplastik merupakan plastik yang terbuat dari bahan alami yang dapat diperbaharui dan mampu terdegradasi lebih cepat sehingga bersifat ramah lingkungan (Kamsiati et al., 2017). Bioplastik dapat dibuat dengan menggunakan bahan yang berasal dari tumbuhan seperti selulosa (Mostafa et al., 2018). Selulosa memiliki keunggulan antara lain jumlahnya melimpah, dapat diperbaharui, mudah terdegradasi secara alami (biodegradable), serta bersifat termoplastik (Isroi et al., 2017). Beberapa bahan alami yang dapat dimanfaatkan sebagai bioplastik antara lain tandan tandan kelapa sawit (Andahera et al., 2019), kulit jagung (Mahfud et al., 2020), kulit buah nangka (Raj dan Ranganathan, 2018), serta linter kapas (Mostafa et al., 2018). Keuntungan dengan penggunaan bahan ramah lingkungan tersebut menyebabkan plastik dapat terdegradasi dalam waktu lebih cepat dibandingkan dengan plastik konvensional yang membutuhkan waktu berabad-abad untuk terdegradasi secara normal.

Indonesia merupakan salah satu produsen padi terbesar di dunia dengan Jawa Timur sebagai provinsi dengan penghasil padi tertinggi. Jawa timur menghasilkan padi sebesar 10.022.387 Ton Gabah Kering Giling (GKG) (Badan Pusat Statistik, 2020). Tingginya angka produksi padi membuat jumlah jerami sebagai hasil samping dari proses produksi padi meningkat. Jumlah limbah jerami yang dihasilkan mencapai $1-1,5 \mathrm{~kg} / \mathrm{kg}$ panenan. Namun, jerami padi dianggap sebagai limbah pertanian sehingga seringkali dibuang atau dibakar. Hal tersebut menyebabkan emisi gas rumah kaca, kontaminasi, dan polusi mengalami peningkatan. Jerami padi mengandung selulosa sekitar 32\%-47\%, hemiselulosa sekitar 19\%-27\%, dan lignin 5\%-24\% (Mukul, 2020). Kandungan selulosa yang relatif tinggi serta ketersediaannya yang cukup melimpah menyebabkan jerami padi dipilih sebagai bahan baku alternatif bioplastik.

Beberapa permasalahan yang disebabkan penggunaan bahan alam dari fiber tanaman yaitu adanya kandungan lignin dan hemiselulosa yang bersifat amorf sehingga perlu dipisahkan terlebih dahulu sebelum proses pembuatan bioplastik. Proses perlakuan fiber alam dilakukan untuk memperbaiki sifat mekanik pada material dengan memperbaiki ikatan antar muka pada fiber alam, meningkatkan jumlah situs aktif dengan mengekspos permukaan serat selulosa, serta meningkatkan indeks kristalinitas serat (Ilyas et al., 2017). Beberapa metode perlakuan fiber dengan tujuan memisahkan kandungan lignin dari selulosa tumbuhan antara lain perlakuan alkali, perlakuan pelarut organik (organosolv treatment), dan perlakuan biologi. Penggunaan metode perlakuan alkali dalam proses delignifikasi dapat dilakukan menggunakan media larutan basa seperti $\mathrm{NaOH}$ atau $\mathrm{KOH}$.

Beberapa penelitian melaporkan tentang penggunaan perlakuan alkali dalam proses pembuatan bioplastik. Mostafa et al. (2018) melakukan sintesis bioplastik dari bahan baku serat rami dengan menggunakan perlakuan alkali berupa larutan $\mathrm{NaOH} 5 \%$ b/v. Hasil penelitian menunjukkan bahwa proses delignifikasi tersebut dapat menghilangkan kadar lignin sehingga menghasilkan bioplastik dengan kemampuan degradasi sebesar 41-44\% selama 14 hari. 
Elhussieny et al. (2020) mensintesis bioplastik dari selulosa jerami-kitosan menggunakan perlakuan alkali $\mathrm{NaOH}$ 17,5\%. Hasil penelitian tersebut mnghasilkan bioplastic dengan kuat tarik sebesar $23 \mathrm{Mpa}$ pada perbandingan jerami-kitosan sebesar 3,5:10 dan dapat terdegradasi selama 100 hari. Proses pretreatment jerami tersebut dilakukan menggunakan larutan $\mathrm{NaOH} 17,5 \% \mathrm{~b} / \mathrm{v}$ selama 2 jam dengan suhu $100^{\circ} \mathrm{C}$ (Elhussieny et al., 2020). Namun, beberapa kelemahan dari penggunaan larutan alkali cenderung menghasilkan serat dengan kandungan selulosa yang rendah serta menghasilkan air limbah yang harus ditangani secara tepat (Ferreira et al., 2021). Selain itu, proses perlakuan biologi memerlukan waktu yang relatif lama serta pertumbuhan mikroorganisme dipengaruhi kondisi lingkungan sehingga kurang efektif untuk pembuatan bioplastik (Pommet et al., 2008).

Perlakuan pelarut organik merupakan metode delignifikasi yang efektif untuk menghilangkan kandungan lignin dan hemiselulosa dari fiber alam. Beberapa kelebihan perlakuan pelarut organik antara lain memiliki efisiensi pemisahan lignin yang tinggi serta kemampuan pelarut yang dapat direcovery kembali setelah digunakan (Zhao et al., 2009). Sebagian besar lignin dan hemiselulosa dapat dihilangkan dengan pelarut organik. Selulosa yang diperoleh dari proses perlakuan pelarut organik merupakan selulosa dengan kemurnian tinggi (Zhao et al., 2009). Pelarut organik yang sering digunakan dalam proses delignifikasi yaitu metanol dan etanol. Pelarut metanol dengan konsentrasi $50 \%$ dapat mengurangi kadar lignin sebesar $90 \%$ selama 45 menit dengan suhu $160^{\circ} \mathrm{C}$, Namun, penggunaan metanol memiliki kekurangan yaitu membutuhkan katalis asam klorida agar bereaksi secara maksimal. Metanol bersifat racun sehingga harus dioperasikan dengan secara hati-hati (Zhao et al., 2009). Penggunaan Etanol pada proses perlakuan fiber alam tidak membutuhkan katalis asam, lebih aman, toksisitas rendah, serta dapat dioperasikan dengan konsentrasi yang rendah (Correia et al., 2015; Zhao et al., 2009).

Penelitian ini bertujuan untuk mensintesis bioplastik dari bahan baku jerami padi menggunakan perlakuan pelarut organik, serta menganalisis pengaruh rasio massa pati dengan selulosa karakteristik produk bioplastik. Bahan matriks yang digunakan pada penelitian ini berupa pati sedangkan Plasticizer yang digunakan berupa sorbitol yang bersifat aman dan ramah lingkungan. Penelitian ini diharapkan dapat memberikan pengetahuan terhadap pemanfaatan jerami sebagai bahan dasar pembuatan bioplastik berbasis selulosa sehingga dapat mengurangi dampak negatif akibat penggunaan plastik berbahan minyak bumi.

\section{METODOLOGI}

Bahan yang digunakan pada penelitian ini antara lain jerami padi, etanol 70\% (SAP Chemicals), akuades, $\mathrm{NaOH}$ 99\% (SAP Chemicals), tepung pati, dan sorbitol 99\% (SAP Chemicals). Alat yang digunakan pada penelitian ini antara lain blender, ayakan ukuran 60 mesh, hotplate dan magnetic stirrer (Cimarec), cetakan aluminium berukuran $20 \mathrm{~cm} \times 15 \mathrm{~cm} \times 0,5 \mathrm{~cm}$, peralatan $X$ Ray Difraction (XRD) X'Pert RINT 2200 V Philiph CuKa $(\lambda=1,5418 \AA)$, Scanning Electron Microscope (SEM) (Phenom Pro Dekstop), peralatan Thermal Gravimetry-Diffrential Thermal Analysis (TG-DTA DTG-60H), dan peralatan uji tarik (Instron Universal Testing Machine).

\section{Proses Pembuatan Bioplastik}

Proses pembuatan bioplastik dari limbah jerami terbagi menjadi tiga tahapan antara lain preparasi jerami, proses delignifikasi jerami, serta pencetakan sampel. Tahap preparasi dilakukan melalui penggilingan jerami dilakukan untuk mempermudah proses delignifikasi. Penggilingan dilakukan dengan blender. Penggilingan dilakukan sampai dengan jerami berukuran 60 mesh.

Jerami yang telah halus selanjutnya di lakukan delignifikasi menggunakan metode perlakuan pelarut organik. Sebanyak $100 \mathrm{~g}$ jerami yang dimasukkan ke gelas beker $1000 \mathrm{~mL}$. Jerami selanjutnya direndam di dalam etanol dengan variasi konsentrasi $5 \%$ dan $35 \%$ v/v. Perbandingan jerami halus dan larutan etanol sebesar 1:10 b/v. Campuran dipanaskan dengan suhu $80^{\circ} \mathrm{C}$ selama 2 jam. Setelah dipanaskan, campuran dimasukkan ke didinginkan pada suhu $0^{\circ} \mathrm{C}$ selama 24 jam. Jerami selanjutnya ditambahkan $500 \mathrm{~mL} \mathrm{NaOH} 1$ $\% \mathrm{~b} / \mathrm{v}$ untuk menghilangkan kandungan lignin yang tersisa. Padatan disaring dan dicuci dengan 
akuades untuk menghilangkan kandungan sisa etanol dan $\mathrm{NaOH}$. Padatan selulosa selanjutnya dikeringkan di dalam oven pada suhu $50^{\circ} \mathrm{C}$ selama 3 jam.

Pembuatan bioplastik diawali dengan merendam selulosa dalam asam asetat $10 \%$ selama 2 jam pada suhu $90^{\circ} \mathrm{C}$ untuk memodifikasi selulosa agar seratnya lebih halus dan bersih. Selulosa disaring dan dicuci menggunakan akuades bersih lalu dikeringkan dalam oven. Bioplastik dibuat dengan mencampurkan pati dan selulosa pada perbandingan 1:0,5; 1:1, 1:1,5. Campuran tersebut selanjutnya ditambahkan akuades $65 \mathrm{~mL}$ dan sorbitol sebagai plasticizer Massa sorbitol yang ditambahkan sebanyak 30\% dari massa pati. Larutan diaduk dan dipanaskan selama 10-15 menit dengan suhu $90^{\circ} \mathrm{C}$ hingga mengental. Larutan bioplastik ini kemudian dicetak dengan ukuran $25 \mathrm{~cm} \times 15 \mathrm{~cm}$ dengan ketebalan $0,2 \mathrm{~cm}$ dan dikeringkan dalam suhu ruangan hingga terbentuk lembaran bioplastik.

\section{Karakterisasi dan Parameter Uji}

Uji Scanning Electron Microscope (SEM) dilakukan untuk mengetahui morfologi permukaan sampel jerami dan bioplastik. Uji XRD dilakukan dengan sudut $2 \theta \quad 10^{\circ}-90^{\circ}$ untuk mengetahui kristalinitas dari jerami sebelum dan sesudah perlakuan pelarut organik. Persentase kristalinitas (CR) dari jerami sebelum dan setelah delignifikasi hasil XRD dapat dihitung menggunakan persamaan (Oushabi et al., 2017):

$$
\mathrm{CR}(\%)=\frac{\mathrm{I}_{002}}{\mathrm{I}_{002}+\mathrm{I}_{\mathrm{am}}} \times 100
$$

Keterangan $\mathrm{I}_{002}$ merupakan intensitas maksimum pada refleksi kisi 002 dari kristalografi selulosa pada $2 \theta=21,4^{\circ}$ dan $\mathrm{I}_{\mathrm{am}}$ merupakan intensitas pada bagian amorf pada $2 \theta=15,2^{\circ}$. Kadar selulosa dan lignin dari jerami sebelum dan setelah delignifikasi di menggunakan metode Chesson-Datta.

Kekuatan tarik dan elongasi bioplastik diukur diuji menggunakan menggunakan alat uji tarik berdasarkan metode ASTM D-882. Kuat tarik ditentukan berdasarkan gaya maksimum saat film putus dan perpanjangan putus ditentukan dari pemanjangan hingga film putus.

Uji ketahanan termal terhadap sampel bioplastik menggunakan metode TG-DTA.
Pengujian TG-DTA dilakukan menggunakan suhu pemanasan antara $30-550^{\circ} \mathrm{C}$ dengan menggunakan pan aluminium serta atmosfer gas nitrogen. Laju pemanasan pada proses TG-DTA sebesar $10^{\circ} \mathrm{C} /$ menit.

Uji laju transmisi uap air bioplastik menggunakan metode gravimetri berdasarkan ASTM E-96 dilakukan dengan meletakkan film berukuran $5 \times 5 \mathrm{~cm}$ pada permukaan atas cawan yang berisi $10 \mathrm{ml}$ akuades dan diletakkan pada desikator selama 24 jam perhitungan laju transmisi uap air didasarkan pada pertambahan berat film setelah pengujian. Perhitungan laju transmisi uap air dapat dihitung menggunakan persamaan:

$$
\text { Laju_Transmisi_Uap_Air }=\frac{\mathrm{W}_{1}-\mathrm{W}_{\mathrm{O}}}{\mathrm{T} . \mathrm{A}}
$$

Keterangan: $\mathrm{W}_{1}=$ massa bioplastik setelah kontak dengan uap air (g); $W_{o}=$ massa bioplastik sebelum kontak dengan uap air (g); $\mathrm{T}$ = waktu kontak (hari); $A=$ luas permukaan bioplastik $\left(\mathrm{m}^{2}\right)$

Tingkat degradasi dilakukan menggunakan metode soil burial test dengan melakukan preparasi bioplastik dengan ukuran $5 \times 1 \mathrm{~cm}$. Bioplastik selanjutnya dikeringkan dalam desikator dan ditimbang berat sebelum penguburan. Sampel dikubur dalam tanah selama 10 hari. Sampel yang telah dikubur selanjutnya diambil dari tanah dan dibersihkan dari kotoran yang melekat. Kemudian tempatkan ke desikator serta ditimbang dan diperoleh berat akhir setelah penguburan. Tingkat degradasi bioplastik dinyatakan dalam bentuk persentase massa yang hilang serta dapat dihitung dengan dengan persamaan (Susilawati et al., 2011):

$$
\% \text { Kehilangan massa }=\frac{W_{0}-W_{1}}{W_{0}} \times 100 \%
$$

Keterangan: $W_{1}=$ massa bioplastik sebelum penguburan $(\mathrm{g}) ; \mathrm{W}_{0}=$ massa bioplastik setelah penguburan $(\mathrm{g})$

\section{HASIL DAN PEMBAHASAN}

\section{Proses Delignifikasi}

Perlakuan pelarut organik merupakan proses awal yang digunakan untuk delignifikasi 
sehingga dapat meningkatkan kadar selulosa pada jerami. Proses delignifikasi bertujuan untuk membuka struktur lignoselulosa agar selulosa menjadi lebih mudah diakses. Kondisi jerami sebelum dan setelah delignifikasi etanol dapat diamati pada Gambar 1

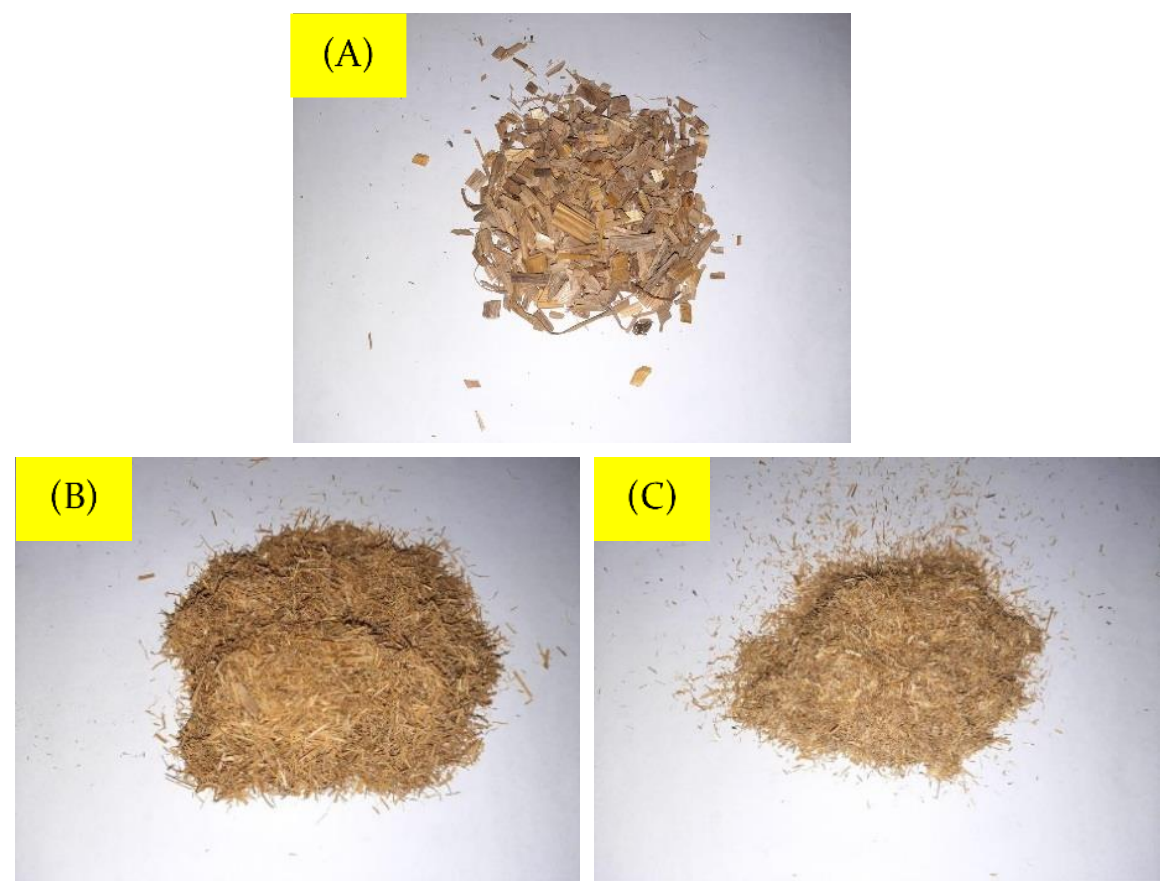

Gambar 1. Jerami sebelum dan setelah pretreatment organosolv (A) sebelum pretreatment (B) treatment $5 \%$ etanol dan (C) treatment 35\% etanol

Proses delignifikasi dapat melarutkan kadar lignin di dalam bahan sehingga dapat memudahkan proses pemisahan lignin dengan serat. Delignifikasi menggunakan etanol mengakibatkan kerusakan terhadap struktur lignin dari kandungan lignoselulosa dan mengubah lignoselulosa menjadi fiber dengan kandungan selulosa yang tinggi (Kurniaty et al., 2017).

Gambar 1 menunjukkan keadaan jerami sebelum dilakukan perlakuan pelarut organik cenderung berwarna cerah dan memiliki tekstur kasar. Tekstur dari jerami setelah perlakuan pelarut organik cenderung halus dan berwarna lebih gelao dibandingkan kondisi sebelum proses delignifikasi. Hal tersebut disebabkan larutan etanol yang digunakan pada proses perlakuan pelarut organik menyebabkan hidrolisis lignoselulosa menghasilkan fiber dengan kandungan selulosa yang tinggi sehingga menyebabkan perubahan warna jerami menjadi gelap (Safitri et al., 2018).

Uji Chesson-Datta dilakukan untuk mengetahui perbedaan jumlah kandungan selulosa dan lignin sebelum dan sesudah proses delignifikasi. Hasil uji Chesson-Datta yang telah dilakukan maka diperoleh kadar selulosa dan lignin sebagaimana yang disajikan pada Tabel 1 . Hasil analisis menunjukkan bahwa kandungan selulosa dari jerami sebelum delignifikasi diperoleh sebesar 33,47\%, dan lignin sebesar $16,11 \%$. Hasil delignifikasi yang diharapkan adalah semakin besar kadar selulosa serta semakin kecil lignin (Roza, 2009). Berdasarkan uji yang telah dilakukan dapat diketahui bahwa kandungan selulosa sebelum delignifikasi dan sesudah delignifikasi mengalami peningkatan. Kandungan selulosa yang paling tinggi didapatkan dengan delignifikasi etanol $5 \%$ yakni sebesar $42,49 \%$ dan kandungan lignin sebesar 13,13\%.

Hasil penelitian menunjukkan bahwa pada konsentrasi etanol 35\% terjadi penurunan kadar selulosa. Hal tersebut disebabkan air dan etanol merupakan dua bahan yang bersifat nukleofilik sehingga menghasilkan larutan yang baik untuk menginisiasi pembelahan serta melarutkan bagian 
lignin. konsentrasi etanol yang relatif tinggi mengarah pada proses presipitasi lignin pada permukaan lignoselulosa sehingga cenderung mengurangi efektifitas dari delignifikasi (Hamzah et al., 2020).

Pengujian SEM dilakukan pada sampel jerami sebelum delignifikasi serta sampel jerami hasil proses delignifikasi yang memiliki kadar selulosa tertinggi. Hasil SEM pada Gambar 2 menunjukkan bahwa morfologi permukaan jerami sebelum proses delignifikasi menunjukkan struktur yang halus serta rapat. Jerami padi tersebut masih tertutup oleh lapisan lignin, hemiselulosa, komponen lain yang mengikat selulosa, serta zat pengotor lainnya (Nata et al., 2014).

Hasil SEM pada jerami yang telah mengalami delignifikasi dengan etanol memiliki struktur berbentuk fiber dengan struktur permukaannya lebih kasar dan pecah. Larutan etanol yang digunakan dalam proses delignifikasi dapat menyerang dan merusak struktur lignin pada jerami padi. Proses delignifikasi dapat melarutkan lignin dan hemiselulosa dan menyebabkan pengembangan pada struktur selulosa (Nata et al., 2014).

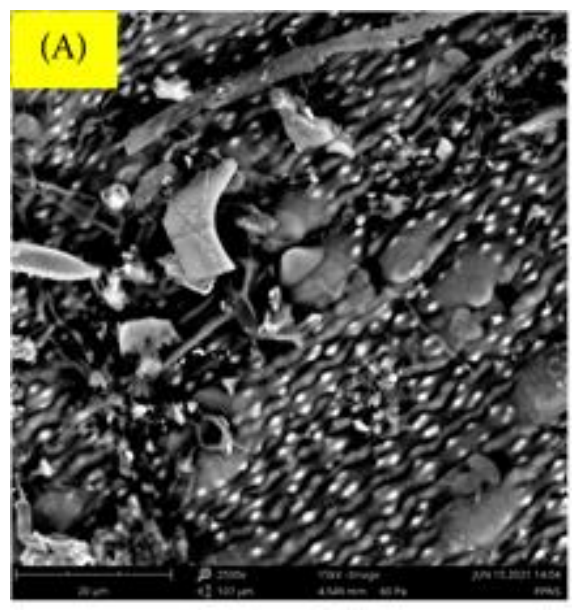

Gambar 3 menunjukkan hasil analisis XRD dari sampel jerami dan setelah proses delignifikasi menggunakan etanol $5 \%$. Jerami sebelum dan setelah delignifikasi mempunyai puncak tertinggi berada pada daerah $2 \theta$ 21,4\%. Perlakuan delignifikasi menyebabkan peningkatan nilai persen kristalinitas pada jerami. Persen kristalinitas (CR\%) dihitung berdasarkan persamaan (1) dan didapatkan nilai CR\% jerami sebelum delignifikasi sebesar 59,29\% sedangkan untuk nilai CR\% jerami sesudah delignifikasi diperoleh sebesar 62,55\%. Peningkatan nilai persen kristalinitas merupakan hasil dari penurunan kadar lignin yang besifat amorf akibat dari proses delignifikasi yang berlangsung sehingga menyisakan komponen selulosa yang bersifat kristal (Setiawan et al., 2020).

\section{Karakteristik Bioplastik}

Tabel 2. Menunjukkan data kuat tarik dan regangan dari bioplastik. Berdasarkan hasil uji tarik yang telah dilakukan diperoleh hasil tegangan tarik tertinggi pada sampel bioplastik yang dibuat dengan perbandingan pati dengan selulosa sebesar $1: 0,5$ serta pada kondisi

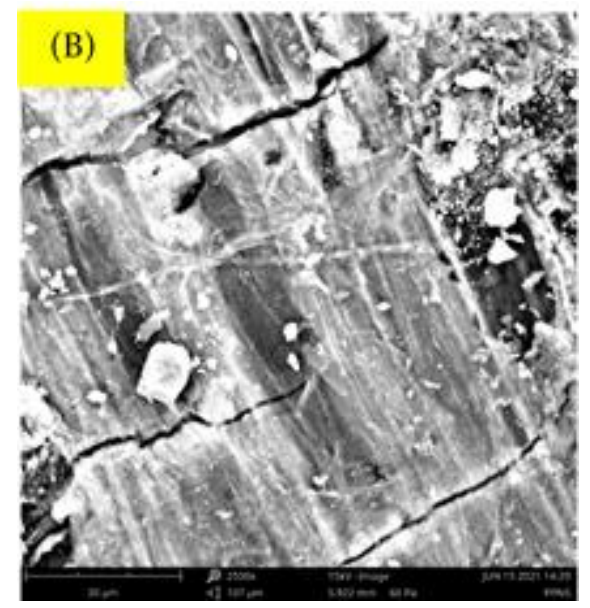

Gambar 2. Morfologi jerami (A) sebelum dan (B) Setelah delignifikasi etanol 5\%

Tabel 1. Hasil Uji Selulosa dan Lignin

\begin{tabular}{lcc}
\hline \multicolumn{1}{c}{ Sampel Jerami } & Kadar (\% wt) & \\
\cline { 2 - 3 } & Selulosa & Lignin \\
\hline Tanpa Delignifikasi & 33,47 & 16,11 \\
Etanol 5\% & 42,49 & 13,13 \\
Etanol 35\% & 37,15 & 15,11 \\
\hline
\end{tabular}




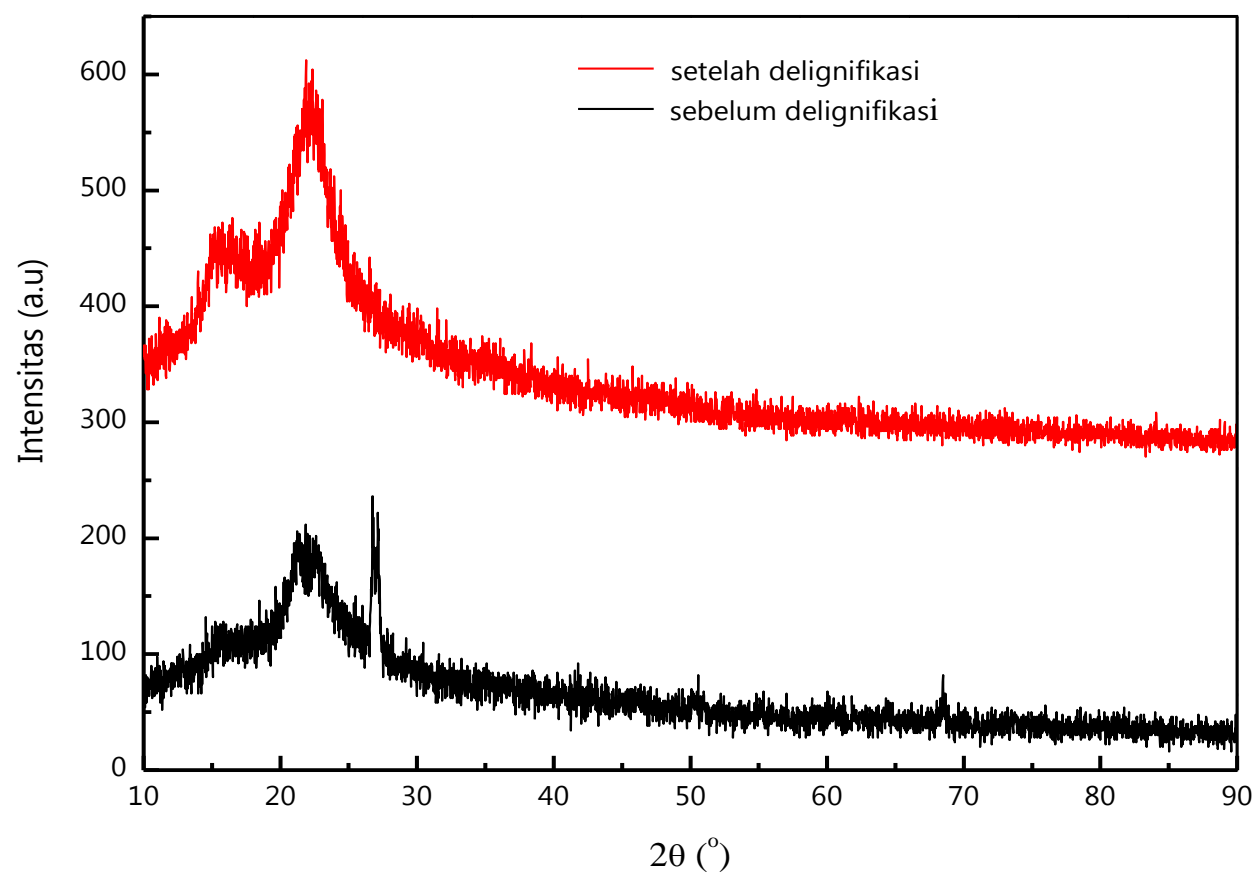

Gambar 3. Spektra XRD dari Jerami sebelum dan Setelah delignifikasi etanol 5\%

delignifikasi menggunakan etanol 35\%. Besarnya kuat tarik yang diperoleh sebesar 8,773 Mpa dengan nilai regangan sebesar $6,5 \%$. Delignifikasi menggunakan etanol $35 \%$ menghasilkan kandungan selulosa yang paling rendah sehingga cenderung menghasilkan bioplastik dengan sifat mekanik yang baik. Octaviana (2016) dalam penelitiannya melaporkan bahwa tingginya kandungan selulosa pada bioplastik dapat menyebabkan bioplastik bersifat rapuh. Hal tersebut disebabkan sifat dari selulosa kering cenderung bersifat keras serta mudah rapuh. Beberapa Penelitian serupa telah melaporkan sifat mekanik pada bioplastik. Mukul et al. (2020) mensintesis bioplastik dari kitosan dan selulosa jerami dengan perbandingan massa 4:10 menghasilkan kuat tarik sebesar $13,8 \mathrm{MPa}$, elongasi 316.5\%. Elhussieny et. al (2020) mensintesis Bioplastik dari selulosa jerami dan kitosan dengan perbandingan massa 3,5: 10 memiliki kuat tarik $23 \mathrm{Mpa}$.

Gambar 4 menunjukkan hasil TG-DTA sampel bioplastic dengan rasio massa pati dengan selulosa $1: 0,5$ dengan perlakuan larutan etanol $35 \%$. Hasil uji menunjukkan bahwa pada grafik TG pada kisaran suhu $30^{\circ} \mathrm{C}-150^{\circ} \mathrm{C}$ terjadi penurunan massa sebesar 7,81\% dari massa awal bioplastik. Pengurangan massa awal pada bioplastik terjadi akibat hilangnya air yang terkandung dalam bioplastik akibat penguapan. Pengurangan massa dari bioplastik kembali dapat terlihat jelas pada kisaran suhu $150^{\circ} \mathrm{C}-350^{\circ} \mathrm{C}$. Degradasi selulosa dan lignin dapat diamati melalui grafik DTA. Pada kisaran suhu $100^{\circ} \mathrm{C}$ terdapat puncak yang rendah. Pada kisaran suhu $200^{\circ} \mathrm{C}-250^{\circ} \mathrm{C}$ terdapat puncak dekomposisi selulosa. Pada kisaran suhu $320^{\circ} \mathrm{C}$ $350^{\circ} \mathrm{C}$ terjadi dekomposisi dari lignin (Ramirez, 2014). Dekomposisi hemiselulosa terjadi pada suhu $200^{\circ} \mathrm{C}-260^{\circ} \mathrm{C}$, dekomposisi selulosa terjadi pada suhu $240^{\circ} \mathrm{C}-350^{\circ} \mathrm{C}$ dan dekomposisi lignin terjadi pada suhu $250^{\circ} \mathrm{C}-500^{\circ} \mathrm{C}$. Berdasarkan hasil pengujian TG yang telah dilakukan dapat diketahui bahwa terjadi pengurangan massa bioplastik sebesar $81,01 \%$ dari massa awal. Beberapa hasil penelitian serupa telah dilaporkan tentang ketahanan termal dari material bioplastik. Sjafarina et al. (2020) melaporkan bahwa uji ketahanan termal bioplastik selulosa jerami menghasilkan pengurangan massa sebesar $42 \%$ pada suhu $600^{\circ} \mathrm{C}$. Agustin et al. (2014) melaporkan bahwa uji ketahanan termal bioplastik dari pati dan jerami dengan kondisi rasio massa pati dengan selulosa nanokristal menghasilkan pengurangan massa sebesar $79,63 \%$ pada suhu $600^{\circ} \mathrm{C}$. 
Hasil SEM pada Gambar 5 dapat diamati bahwa permukaan bioplastik terlihat tidak rata. Selain itu, terdapat bagian dari bioplastik yang menggumpal serta ada sebagian daerah fiber yang terpisah dengan matriks pati. Keadaan ini dapat disebabkan oleh kurangnya homogenitas antara matriks pati kanji dengan fiber selulosa. Kurangnya homogenitas dari bioplastik akan menyebabkan melemahnya ikatan antar muka dari permukaan fiber dan dengan matriks dan berpotensi menurunkan sifat mekanik bioplastik (Mahfud et al., 2020).

Gambar 6 menunjukkan hasil pengujian sifat transmisi uap air dari sampel bioplastik. Hasil pengujian menunjukkan bahwa terdapat kecenderungan penurunan nilai laju transmisi uap seiring dengan meningkatnya massa selulosa. Penurunan nilai laju transmisi uap disebabkan karena meningkatnya padatan terlarut di dalam larutan film membentuk ikatan hidrogen yang lebih kuat sehingga menghasilkan struktur yang kompak. Struktur yang kompak dapat menghambat difusi uap air melewati bioplastik sehingga nilai laju transmisi uap kecil (Breemer et al., 2012). Hasil pengujian sifat transmisi uap air diperoleh nilai minimum sebesar $12 \mathrm{~g} / \mathrm{m}^{2}$.hari yakni bioplastik dengan rasio pati dengan selulosa $1: 1,5$ serta didelignifikasi pada kondisi etanol $35 \%$. Hasil penelitian serupa telah dilakukan antara lain Rohman (2016) mendapatkan nilai laju transmisi

Tabel 2 Hasil Uji Tarik

\begin{tabular}{cccc}
\hline Rasio pati : selulosa & Konsentrasi Etanol (\%) & Tegangan (MPa) & Regangan (\%) \\
\hline \multirow{2}{*}{$1: 0,5$} & 5 & 5,415 & 2,6 \\
& 35 & 8,773 & 6,5 \\
$1: 1$ & 5 & 5,153 & 8,1 \\
& 35 & 6,354 & 5,2 \\
\multirow{2}{*}{$1: 1,5$} & 5 & 5,114 & 5,8 \\
& 35 & 4,828 & 5,6 \\
\hline
\end{tabular}

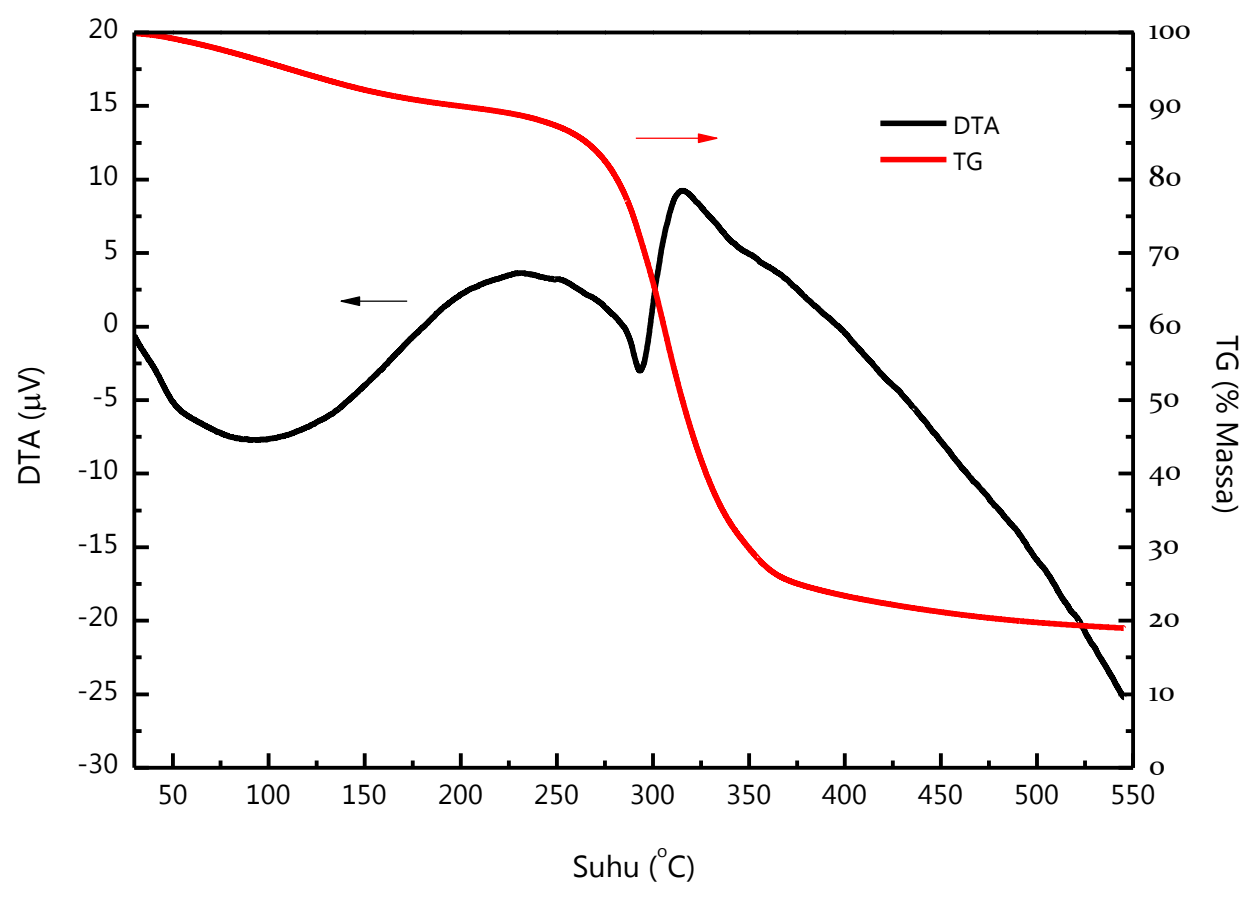

Gambar 4. TG-DTA bioplastik 

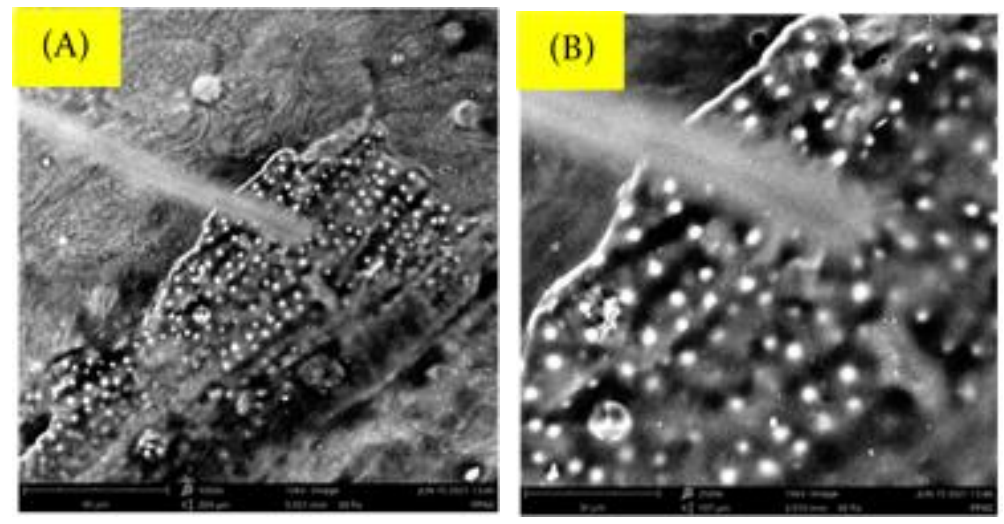

Gambar 5. Morfologi bioplastik (a) perbesaran 1000x (b) perbesaran 2500x

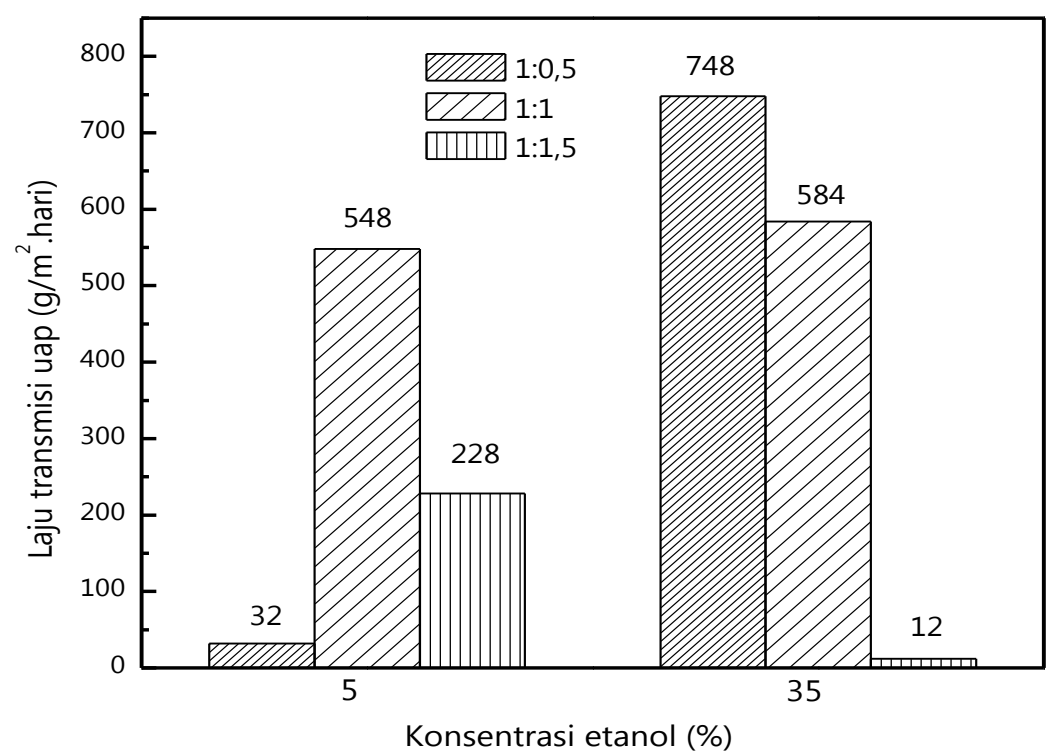

Gambar 6. Hasil uji transmisi uap air bioplastik

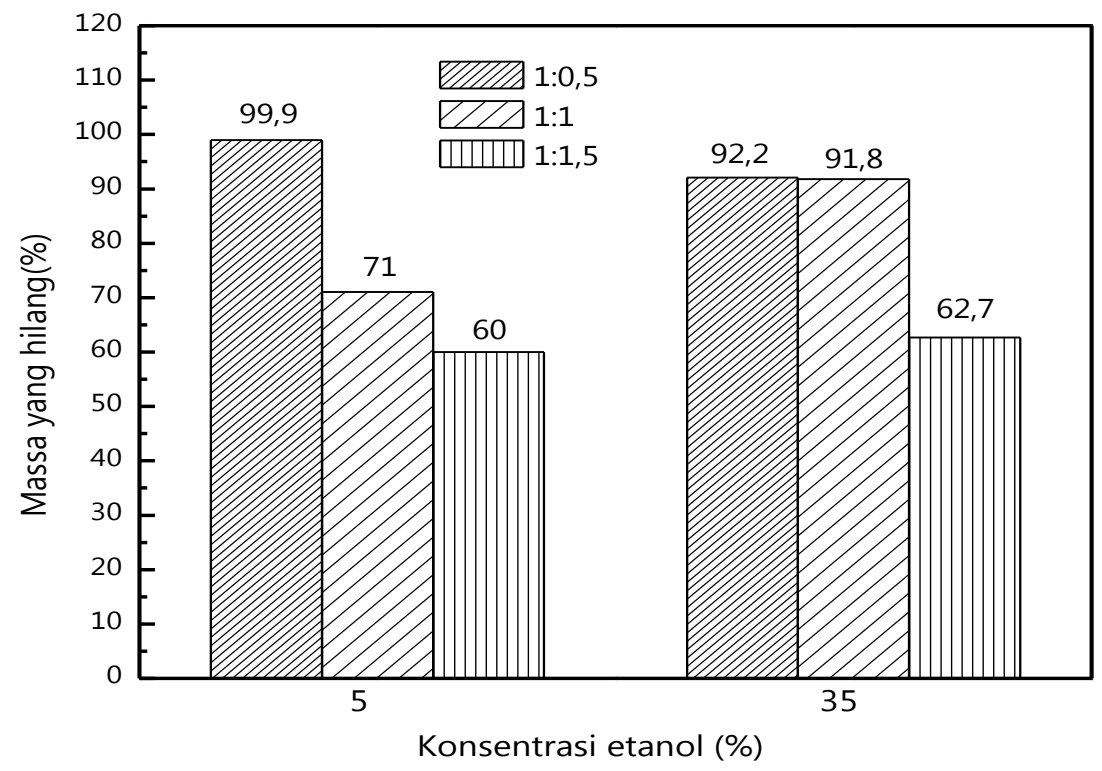

Gambar 7. Hasil uji degradasi bioplastik 
uap dari bioplastik kitosan dengan plasticizer CMC minimal sebesar $5,8 \mathrm{~g} / \mathrm{m}^{2}$.hari dan mkasimal sebesar $13,37 \mathrm{~g} / \mathrm{m}^{2}$.hari. Breemer et al. (2012) mendapatkan nilai laju transmisi uap bioplastik dari pati ubi sebesar minimal sebesar 169,68 $\mathrm{g} / \mathrm{m}^{2}$.hari serta maksimal sebesar $296,16 \mathrm{~g} / \mathrm{m}^{2}$.hari.

Gambar 7 menunjukkan hasil pengujian tingkat degradasi bioplastik. Hasil pengujian menunjukkan bahwa persentase massa hilang bioplastik tertinggi dalam kurun waktu 10 hari adalah bioplastik dengan rasio pati dengan selulosa 1:0,5 serta didelignifikasi menggunakan etanol $5 \%$ yakni sebesar $99,9 \%$. Penurunan massa bioplastik mengindikasikan terjadinya penguraian bioplastik oleh aktifitas mikroba. Aktifitas mikroba di dalam tanah akan mendekomposisi polimer pati dan selulosa menjadi potongan-potongan kecil di dalam tanah.

Hasil penelitian menunjukkan bahwa semakin kecil perbandingan massa pati dengan selulosa maka tingkat degradasi bioplastik cenderung semakin baik. Adanya Pengaruh kekuatan ikatan antar molekul hidrogen pati dengan selulosa menyebabkan bioplastik lebih mudah berinteraksi dengan mikroba di dalam tanah (Maladi, 2019). Selain itu, tingginya kadar selulosa dalam bioplastik cenderung menyebabkan ikatan polimer pati-selulosa semakin kuat sehingga bioplastik akan lebih sulit terurai (Panjaitan et al., 2017). Beberapa peneliti telah melaporkan hasil yang serupa terhadap tingkat degradasi bioplastik. Panjaitan et al. (2017) dalam penelitiannya menyebutkan bahwa bioplastik berbahan dasar selulosa batang pisang dan pati umbi talas memiliki nilai \% massa hilang sebesar 40\% selama 4 hari dan Maladi (2019) menyebutkan bahwa bioplastik selulosa jerami padi dan pati kulit singkong memiliki \% massa hilang sebanyak $71 \%$ selama 56 hari pengujian.

\section{KESIMPULAN}

Hasil penelitian dalam proses sintesis bioplastic menunjukkan bahwa peningkatan massa pati di dalam bioplastik menyebabkan kuat tarik semakin meningkat. Hasil kuat tarik bioplastik tertinggi diperoleh pada rasio pati dan selulosa 1:0,5 dengan kondisi delignifikasi etanol 35\%. Nilai tegangan yang diperoleh tersebut sebesar 8,773 Mpa. Peningkatan massa selulosa menyebabkan turunnya laju transmisi uap pada bioplastik. Nilai laju transmisi uap terkecil diperoleh pada bioplastik dengan perbandingan massa pati dan selulosa $1: 1,5$ dan didelignifikasi menggunakan etanol 35\% yakni sebesar $12 \mathrm{~g} / \mathrm{m}^{2}$.hari. Peningkatan kandungan selulosa dalam bioplastik menyebabkan tingkat degradasi bioplastik semakin tinggi. Nilai persentase degradasi tertinggi diperoleh pada sampel dengan perbandingan massa pati dan selulosa sebesar 1:0,5 dan didelignifikasi dengan etanol $5 \%$ yakni sebesar 99,9\%. Pengembangan bioplastik berbahan baku jerami padi diharapkan dapat mengurangi ketergantungan terhadap penggunaan plastik konvensional sehingga dapat menurunkan timbulan serta dampak negatif terhadap lingkungan.

\section{DAFTAR PUSTAKA}

Agustin, M.B., Ahmmad, B., Alonzo, S.M.M., \& Patriana, M.F., 2014, Bioplastic Based on Starch and Cellulose Nanocrystals From Rice Straw, Journal of Reinforced Plastics and Composites, 33(24): 2205-2213.

Andahera, C, Sholikhah, I., Islamiati, D.A., \& Pusfitasari, M.D., 2019, Pengaruh Penambahan Jenis dan Konsentrasi Plasticizer Terhadap Kualitas Bioplastik Berbasis Selulosa dari Tandan Kosong Kelapa Sawit, Indonesian Journal of Pure and Applied Chemistry, 2(2): 46-54.

Badan Pusat Statistik, 2020, Luas Panen dan Produksi Padi di Indonesia 2020, Jakarta, Indonesia: BPS.

Bayer, I.S., Guzman-Puyol, S., Heredia-Guerrero, J.A., Ceseracciu, L., Pignatelli, F., Ruffilli, R., Cingolani, R., \& Athanassiou, A., 2014, Direct transformation of Edible Vegetable Waste Into Bioplastics, Macromolecules, 47: 5135-5143.

Breemer, R., Polnaya, F.J. \& Pattipeilohy, J., 2012, Sifat Mekanik dan Laju Transmisi Uap Air Edible Film Pati Ubi Jalar, Seminar Nasional Pangan 2012 UPN Veteran, Yogyakarta, Nopember 13.

Correia, V. C., Curvelo, A.A.S., Marabezi, K, \& Almeida, A.E.F.S.H., 2015, Bamboo Cellulosic Pulp Produced by The Ethanol/Water Process For Reinforcement Applications, Ciência Florestal, 25(1): 127-135. 
Elhussieny,A., Faisal, M., D'Angelo, G., Aboulkhair, N.T., Everitt, N.M., \& Fahim, I.S., 2020, Valorisation of Shrimp and Rice Straw Waste Into Food Packaging Applications, Ain Shams Engineering Journal, 11(4), 1219-1226.

Ferreira, J.A., Lourenco, A., Margado, F., Duarte, L.C., Roseiro, L.B., Fernandes, M.C., Pereira, H., \& Carvalheiro, F., 2021, Delignification of Cistus ladanifer Biomass by Organosolv and Alkali Processes, Energies, 14(4): 1-21.

Hahladakis, J.N., Velis, C.A.,Weber, R., Iacovidou, E., \& Purnell, P., 2018, An Overview of Chemical Additives Present in Plastics: Migration, Release, Fate and Environmental Impact During Their Use, Disposal and Recycling, Journal of Hazardous Materials, 344: 179-199.

Hamzah, H.M., Bowra, S., \& Cox, P, 2020, Effects of Ethanol Concentration on Organosolv Lignin Precipitation and Aggregation from Miscanthus x giganteus, Processes, 8(7): 1-16.

Ilyas, R. A., Sapuan, S.M., Ishak, M.R., \& Zainudin, E.S., 2017, Effect of Delignification on the Physical, Thermal, Chemical and Structural Properties of Sugar Palm Fibre, BioResources, 12(4): 8734- 8754.

Isroi, I., Cifriadi, A., Panji, T., Wibowo, N.A., \& Syamsu, K., 2017, Bioplastic Production from Cellulose of Oil Palm Empty Fruit Bunch, IOP Conf. Series: Earth and Environmental Science, 65: 012011.

Kamsiati, E., Herawati, H., \& Purwani, E.Y., 2017, Potensi Pengembangan Plastik Biodegradable Berbasis Pati Sagu dan Ubikayu di Indonesia, Jurnal Litbang Pertanian, 36(2): 67-76.

Kurniaty, I., Habibah, U., Yustiana, D., \& Fajriah, I., 2017, Proses Delignifikasi Menggunakan $\mathrm{NaOH}$ dan Amonia $\left(\mathrm{NH}_{3}\right)$ pada Tempurung Kelapa, Jurnal Integrasi Proses, 6(4): 197-201.

Mahfud, R.N.M., Setiawan, A., \& Mayangsari, N.E., 2020, Pengaruh Penambahan Carboxy Methyl Cellulose dalam Biodegradable Plastik Kulit Jagung dengan Sorbitol sebagai Plasticizer, Conference Proceeding on Waste Treatment Technology $3^{\text {rd }}$, Surabaya, Oktober 3.

Maladi, I., 2019, Pembuatan Bioplastik Berbahan Dasar Pati Kulit Singkong (Manihot utilissima) dengan Penguat Selulosa Jerami Padi, Polivinil Alkohol, Dan Bio-Compatible Zink
Oksida, Skripsi, Universitas Islam Negeri Syarif Hidayatullah, Jakarta.

Mostafa, N.A., Farag, A.A., Hala M. Abo-dief, H.M., \& Tayeb, A.M., 2018, Production of Biodegradable Plastic from Agricultural Wastes, Arabian Journal of Chemistry, 11(4): 546-553.

Mukul, S., 2020, Production of Bioplastics and Sustainable Packaging Materials from Rice Straw to Eradicate Stubble Burning: A MiniReview, Environment Conservation Journal, 21(3): 1-5.

Nata, I.F., Prayogo, J.H., \& Arianto, T, 2014, Produksi Bioetanol dari Alkali-Pretreatment Jerami Padi dengan Proses Simultaneous Sacharification and Fermentation (SSF), Konversi, 3(1): 10-16.

Octaviana, M., 2016, Optimasi Preparasi Mikrokristalin Selulosa dari Sekam Padi Menggunakan $\mathrm{H}_{2} \mathrm{O}_{2}$ Dan $\mathrm{NaOCl}$ Untuk Sintesis CMC (Carboxymethyl Cellulose), Skripsi, Universitas Negeri Semarang, Semarang.

Oushabi, A., Sair, S., Hassani, F.O.,Abboud, Y., Tanane, O., \& El Bouari, A., 2017, The Effect of Alkali Treatment on Mechanical, Morphological, and Thermal Properties of Date Palm Fibers (DPFs): Study of the Interface of DPF-Polyurethane Composite, South African Journal of Chemical Engineering, 23: 116-123.

Panjaitan, R.M., Irdoni, I., \& Bahruddin, B., 2017, Pengaruh Kadar dan Ukuran Selulosa Berbasis Batang Pisang Terhadap Sifat dan Morfologi Bioplastik Berbahan Pati Umbi Talas, Jurnal Online Mahasiswa Fakultas Teknik Universitas Riau, 4(1): 1-7.

Pommet, M., Juntaro, J., Heng, J.Y., Mantalaris, A., Lee, A.F., Wilson, K., Kalinka, G., \& Shaffer, M.S., 2008, Surface Modification of Natural Fibers Using Bacteria: Depositing Bacterial Cellulose Onto Natural Fibers to Create Hierarchical Fiber Reinforced Nanocomposites, Biomacromolecules, 9(6): 1643-1651.

Raj, A.A.S., \& Ranganathan, T.V., 2018, Characterization of Cellulose from Jackfruit (Artocarpus integer) Peel, Journal of Pharmacy Research, 12(3): 311-315. 
Ramirez, M.G.L., Kestur, S.G., Gonzalez, R.M., Iwakiri, S., de Muniz, G.B., \& Sahagun, T.S.F., 2014, Bio-Composites of Cassava StarchGreen Coconut Fiber: Part II-Structure and Properties, Carbohydrate Polymers, 102: 576-583.

Rohman, M.A., 2016, Pengaruh Penambahan Glutaraldehida terhadap Karakteristik Film Bioplastik Kitosan Terplastis Carboxy Methyl Cellulose (CMC), Skripsi, Universitas Airlangga, Surabaya.

Roza, I., 2009, Pengaruh Perbedaan Proses Penyediaan Serat dengan Cara Mekanis Limbah Tandan Kosong Sawit Terhadap Papan Serat, Jurnal Sainstek, 10(1): 9-17.

Safitri, R., Anggita, I.D., Safitri, F.M., \& Ratnadewi, A.A.I., 2018, Pengaruh Konsentrasi Asam Sulfat dalam Proses Hidrolisis Selulosa dari Kulit Buah Naga Merah (Hylocereus costaricensis) untuk Produksi Bioetanol, $9^{\text {th }}$ Industrial Research Workshop and National Seminar Polban (IRONS 2018), Bandung, April 6.

Setiawan, A., Setiani, V., Hardianti, F., \& Puspitasari, D., 2019, Pengaruh Pretreatment
Alkali Terhadap Karakteristik Fiber Sabut Kelapa Sawit dan Pelepah Pisang Sebagai Komposit Polimer, Journal of Research and Technology, 5(2): 120-125.

Sjafarina, H., Syahbanu, I., \& Nurlina, N., 2020, Pengaruh Variasi Komposisi Selulosa Jerami Padi dan Limbah Botol Plastik Polietilen Tereftalat (PET) Terhadap Karakteristik Biodegradable Plastik, Indonesian Journal of Pure and Applied Chemistry, 3(3): 25-32.

Susilawati, S., Musatafa, I., \& Maulina, D., 2011, Biodegradable Plastics From A Mixture of Low Density Polyethylene (LDPE) and Cassava Starch With The Addition of Acrylic Acid, Jurnal Natural, 11(2): 69-73.

Thompson, R.C., Moore, C.J., Vom Saal, F.S., \& Swan, S.H., 2009, Plastics, The Environment and Human Health: Current Consensus and Future Trends. Philosophical Transaction of The Royal Society B: Biological Science, 364 (1526): 2153-22166.

Zhao, X., Cheng, K, \& Liu, D., 2009, Organosolv Pretreatment of Lignocellulosic Biomass For Enzymatic Hydrolysis. Applied Microbiology and Biotechnology, 82: 815-827. 